\title{
Dialektika Pada Laporan Keuangan: Analisa Kinerja Laporan Keuangan Perusahaan Sektor Farmasi yang Terdaftar Di Bursa Efek Indonesia
}

\author{
Ni Ketut Sriwinarti \\ Universitas Bumigora \\ sriwinarti@ universitasbumigora.ac.id
}

\begin{abstract}
Abstark
Penelitian ini memiliki tujuan untuk menganalisa secara mendalam atas laporan keuangan perusahaan publik yang merupakan cerminan kinerja perusahaan secara holistik atau hanya serpihan-serpihan saja yang harus dikumpulkan untuk menjadi suatu keutuhan kinerja perusahaan. Pendekatan penelitian yang digunakan dalam penelitian ini adalah pendekatan dialektika dokumen, yang mana pendekatan ini akan memberikan gambaran tentang proses pencarian kebenaran ilmu pengetahuan, terutama yang tertera dalam teks dokumen baik kata-kata dan angka-angka. Sumber data utama dalam penelitian ini adalah laporan keuangan auditan perusahaan Manufaktur Sub Sektor Farmasi tahun 2018 dan 2019 yang terdaftar di BEI. Berdasarkan analisa yang dilakukan ditemukan bahwasanya $40 \%$ laporan keuangan perusahaan yang tersaji masih terdapat gelembunggelembung sabun yang bermakna terdapat perbedaan nilai pada akun antara laporan 2018 yang tersaji di tahun 2018 dan laporan 2018 yang tersaji di tahun 2019. Konsistensi dan stabilitas dalam penyajian keuangan akan menumbuhkan rasa percaya terhadap perusahaan, namun dari data yang diperoleh hanya $30 \%$ perusahaan yang mampu memberikan rasa perlindungan, $50 \%$ perusahaan menimbulkan rasa curiga, $20 \%$ perusahaan menyajikan laporan keuangan yang tak dapat tercerahkan sehingga dapat memunculkan dampak yang akan menyesatkan para penggunanya dalam pengembalian keputusan ekonomi.
\end{abstract}

Kata Kunci: dialektika, kinerja keuangan, laporan keuangan

\begin{abstract}
This study aims to analyze in depth the financial statements of public companies which are a reflection of the company's holistic performance or only bits and pieces that have to be collected to become the integrity of the company's performance. The research approach used in this research is the document dialectic approach, which this approach will provide an overview of the process of finding the truth of science, especially those listed in the document text both words and numbers. The main data source in this study is the audited financial statements of the Manufacturing companies Sub-Sector Pharmaceutical in 2018 and 2019 which are listed on the IDX. Based on the analysis conducted, it was found that $40 \%$ of the company's financial statements that were presented still contained soap bubbles which meant that there was a difference in the value of the account between the 2018 report presented in 2018 and the 2018 report presented in 2019. Consistency and stability in financial presentation would be foster a sense of trust in the company, but from the data obtained, only 30\% of companies are able to provide a sense of protection, 50\% of companies create suspicion, $20 \%$ of companies present financial reports that cannot be enlightened so that they can have an impact that will mislead users in returning decisions the economy.
\end{abstract}

Keyword: dialectics, financial reports, financial performance 


\section{PENDAHULUAN}

Merawat dan mempertahankan lebih sulit daripada meraihnya. Sebuah ungkapan klasik yang menggambarkan pentingnya seseorang atau sekelompok orang harus berusaha untuk selalu konsisten atau bahkan lebih baik daripada pencapaian sebelumnya. Hal yang sama juga berlaku saat mendirikan perusahaan. Setelah perusahaan berdiri, berjalan hingga mampu terdaftar di Bursa Efek indonesia (BEI) terdapat sejumlah kewajiban yang harus dipenuhi. Mulai dari laporan keuangan hingga laporan ke institusi pemerintah terkait dengan kriteria atau perizinan tertentu yang dimiliki oleh sebuah perusahaan. Laporan keuangan sebagai media komunikasi akan berguna bagi para pemakainya untuk dijadikan dasar pijakan dalam membuat laporan keuangan (yaitu pihak manajemen perusahaan) bahwa laporan keuangan merupakan wujud pertanggungjawaban (stewardship) manajemen atas penggunaan sumber-sumber daya yang dipercayakan kepada mereka. Karena informasi akuntansi (laporan keuangan) merupakan sarana komunikasi yang efektif antara pihak pemakai (investor, kreditor dan lainnya) dan pihak pembuat (manajemen perusahaan), maka data akuntansi yang diberikan harus lebih akurat, dapat dipercaya, serta diproses lebih lanjut oleh penerimanya. Sedangkan pihak lain (akuntan public) yang dianggap mampu menjembatani (perantara) kepentingan pemakai dan pembuat laporan keuangan harus bersikap jujur, bijaksana, dan professional (Mahendra, 2012).

Bagi sebuah perusahaan, menjaga dan meningkatkan kinerja keuangan adalah suatu keharusan agar saham tersebut tetap eksis dan tetap diminati oleh investor. laporan keuangan yang diterbitkan perusahaan merupakan cerminan dari kinerja keuangan perusahaan. Informasi keuangan tersebut mempunyai fungsi sebagai sarana informasi, alat pertanggungjawaban manajemen kepada pemiliki perusahaan, pengambaran terhadap indikator keberhasilan perusahaan dan sebai bahan pertimbangan dalam pengambilan keputusan (Harahap, 2009). Pada awal tahun 2020 tercatat 703 perusahaan yang terdaftar di BEI, hal ini berarti terdapat 703 laporan keuangan yang dapat dilihat oleh publik. namun merujuk pada pengumuman yang dikeluarkan oleh BEI Senin, 10 Agustus 2020, Kadiv Penilaian Perusahaan 1 Bursa Efek Indonesia, Adi Pratomo Aryanto mengatakan berdasarkan pemantauan Bursa hingga tanggal 30 Juli 2020. perusahaan tercatat yang belum menyampaikan laporan keuangan sampai dengan batas maksimal tanggal 30 Juli 2020 ada 30 perusahaan. hal ini berarti bahwa terdapat 30 perusahaan tidak memenuhi kewajibannya untuk melaporkan kinerjanya ke publik.

Halim (2008) mengungkapkan bahwa Permainan angka-angka akuntansi oleh akuntan telah mengindikasikan bahwa laporan keuangan yang dibuat oleh perusahaan tidak mencerminkan realitas perusahaan akan menyebabkan salah dalam mengambil keputusan bisnis dan dapat menyesatkan penggunanya. Dengan demikian patut dipertanyakn tentang praktik penyajian laporan keuangan oleh perusahaan yang go public di pasar modal apakah sudah mencerminkan realitas perusahaan, atau praktik penyajian laporan keuangan tersebut bersifat seremonial (ritual) untuk memenuhi kewajiban di pasar modal. lalu mengapa kewajiban tersebut tidak terpenuhi. Padahal relasi-relasi tanggung jawab perusahaan setidaknya tercermin dalam laporan keuangan perusahaan sebagai representasi serpihanserpihan kinerja perusahaan. Oleh karena itu penulis tertarik untuk menganalisa secara mendalam atas laporan keuangan perusahaan publik yang merupakan cerminan kinerja perusahaan secara holistik atau hanya serpihan-serpihan saja yang harus dikumpulkan untuk menjadi suatu keutuhan kinerja perusahaan. Namun mengingat keterbatasan yang dimiliki sehingga perjalanan kata-kata yang penulis lakukan hanya sebatas pada laporan keuangan auditan dan opini auditor tahun 2018 - 2019, dan melakukan analisa perbandingan terhadap laporan keuangan yang disajikan perusahaan hal ini guna memperoleh Spirit yang menjadi 
kekuatan penulis untuk lebih mendekatkan diri pada fenomena akuntansi dan mendapatkan jawaban mengenai apakah laporan keuangan auditan perusahaan publik benar-benar disajikan dengan wajar?.

\section{TINJAUAN PUSTAKA}

\section{Kinerja Laporan Keuangan}

Laporan keuangan merupakan informasi yang tersaji secara periodik dimana laporan ini diperuntukan untuk pihak manajemen, investor, kreditur dan pihak-pihak lain diluar perusahaan. Menurut Jusup (2005), Laporan keuangan utama yang dihasilkan dari proses akuntansi adalah neraca dan laporan rugi laba. Kedua laporan tersebut menggambarkan posisi keuangan dan hasil-hasil yang dicapai pada periode tertentu oleh suatu organisasi. Laporan keuangan merupakan salah satu sarana penting untuk mengkomunikasikan informasi keuangan kepada pihak-pihak di luar perusahaan. Esensi laporan keuangan sangat penting mengingat dari laporan keuangan berbagai keputusan penting mengenai kelangsungan hidup dari entitas bisnis terjadi. Tujuan utama dari laporan keuangan adalah penyedia informasi yang penting bagi users of information. Dalam Statement of Financial Accounting Concepts (SFAC) No. 1 dijelaskan bahwa tujuan utama dari laporan keuangan adalah untuk menyediakan informasi yang berguna dalam pembuatan keputusan bisnis dan ekonomi. Agar dapat memberikan informasi yang berguna, maka laporan keuangan harus berkualitas. Menyediakan informasi yang berkualitas tinggi adalah penting karena hal tersebut akan secara positif memengaruhi penyedia modal dan pemegang kepentingan lainnya dalam membuat keputusan investasi, kredit, dan keputusan alokasi sumber daya lainnya yang akan meningkatkan efisensi pasar secara keseluruhan (Pongoh,2013).

Analisa Laporan Keuangan sangat penting untuk dilakukan untuk menilai sehat atau tidaknya suatu perusahaan. Sutrisno (2013:8) mengungkapkan bahwa laporan keuangan merupakan hasil akhir dari proses akuntansi yang menghasilkan dua laporan utama yaitu laporan Neraca dan Laporan Laba Rugi. Laporan Keuangan juga dapat menjadi acuan untuk melihat kondisi keuangan yang berguna untuk melihat kinerja dari suatu perusahaan. sedangkan Harjito (2008 : 52) mengungkapkan bahwasanya kinerja keuangan mengindikasikan apakah strategi perusahaan, implementasu strategi dan segala inisiatif perusahaan memperbaiki laba perusahaan. pengukuran kinerja mencerminkan pengukuran hasil atas keputusan strategis, operasi dan pembiayaan dalam suatu perusahaan. kinerja keuangan suatu perusahaan sangat bermanfaat bagi berbagai pihak sperti investor, kreditur, analisis, konsultan keuangan, pialang, pemerintah dan pihak manajemen sendiri.

Orniati (2009) menungkapkan bahwanya kinerja keuangan suatu perusahaan dapat diartikan sebagai prospek atau masa depan, pertumbuhan dan potensi perkembangan yang baik bagi perusahaan. Informasi kinerja keuangan diperlukan untuk menilai perubahan potensial sumber daya ekonomi, yang mungkin dikendalikan di masa depan dan untuk memprediksi kapasitas produksi dari sumber daya yang ada (Barlian, 2003). Pimpinan perusahaan atau manajemen sangat berkepentingan terhadap laporan keuangan yang telah di analisis, karena hasil tersebut dapat dijadikan sebagai alat dalam pengambilan keputusan lebih lanjut untuk masa yang akan datang. Dengan menggunakan analisis rasio, berdasarkan data dari laporan keuangan, akan dapat diketahui hasilhasil finansial yang telah dicapai di waktu-waktu yang lalu, dapat diketahui kelemahan-kelemahan yang dimiliki perusahaan, serta hasil-hasil yang dianggap cukup baik. Hasil analisis historis tersebut sangat penting artinya bagi perbaikan penyusunan rencana yang akan dilakukan di masa datang. Dengan mengetahui kelemahan-kelemahan yang dimiliki oleh perusahaan, dapat diusahakan penyusunan rencana yang lebih baik demi memperbaiki kelemahan-kelemahan tersebut. 
Hasil-hasil yang dianggap sudah cukup baik di waktu lampau harus dipertahankan dan ditingkatkan untuk masa-masa mendatang (Tampubolon, 2005)

\section{Habermas: Dialektika Kritis Terhadap Akuntansi}

Jurgen Habermas hadir sebagai seorang filsuf Jerman yang mau menyegarkan kembali kebuntuan epistemologis Teori Kritis Mazhab Frankfurt generasi pertama. Kebuntuan epistemologis Mazhab Frankfurt tersebut terletak pada ketidakmampuan mereka merumuskan sebuah solusi dari analisis dialektika negatif yang mereka refleksikan sendiri. Dialektika negatif tersebut, jika mau dirumuskan secara singkat, sebenarnya mau menekankan pesimisme masyarakat terhadap rasionalitas yang sebelumnya dianggap mampu menyelamatkan manusia dari kebodohan dan kemiskinan, tetapi kini telah menjadi sumber dari malapetaka didalam peradaban manusia itu sendiri. Berbagai bentuk teknologi hasil temuan dari rasionalitas• kini justru seakan-akan memakan tuannya sendiri, seperti bom atom, yang notabene adalah hasil penemuan brilian dari pengembangan dari teori Einstein, kini menjadi mesin penghancur manusia yang paling efektif.

Praktik akuntansi yang digunakan dalam dunia bisnis sekarang ini tidak lain merupakan konsep yang dibuat dan dihasilkan oleh akuntan. Praktik ini secara niscaya menciptakan dan membentuk realitas sosial yang melingkupi dan hadir secara samar dalam kehidupan sosial masyarakat bisnis. Realitas sosial yang tercipta saat ini adalah realitas sosial yang banyak dipengaruhi oleh semangat kapitalisme sebagai produk dari modernisme yang mengklaim ilmu pengetahuan harus bebas dari nilai. Akibatnya realitas yang hidup dan berkembang adalah realitas yang kering akan nilai (nilai-nilai etika).

Posmodernisme, melihat keadaan semacam itu dan mencoba memberikan semacam pandangan diluar paradigma modernisme dengan menawarkan konsep dekonstruksi (atau geneologi). Gerakan ini muncul karena modernisme sebagaimana yang diklaim oleh posmodernisme telah menciptakan ketidakberesan dalam kehidupan manusia, modernisme tidak saja melibatkan penyebaran hegemoni barat, industrialisasi, urbanisasi, dan konsumerisme, tetapi juga melahirkan rasisme, kesenjangan kaya dan miskin, diskriminasi, pengangguran dan stagnasi. Konsep ini pada dasarnya adalah memasukkan 'sang lain' ke dalam wacana yang sedang dominan yang selama selalu dimarginalkan. 'sang lain' pada posisi yang lebih rendah sehingga hubungan antarparadigma dan antarwacana selama ini sebagai suatu 'dialektika' seperti yang diajarkan Hegel bertransformasi menjadi hubungan 'dialogis' yang saling memperkuat satu sama lainnya (Hardiman, 2002).

Konsekuensi dari ini adalah bahwa 'diri' akuntan, sebagai agen yang mempunyai potensi untuk membentuk realitas sosial, harus mampu memasukkan hati nurani ke dalam setiap wacana yang sedang digeluti dalam wacana modernitas selalu dalam posisi marginal, sedangkan posisi sentral adalah rasio. Dengan menempatkan hati nurani yang sejajar dengan rasio, diri akuntan akan mampu melakukan rekonstruksi akuntansi. Rekonstruksi akuntansi dipandang perlu, karena akuntansi juga mempunyai kuasa untuk membentuk realitas sosial. Oleh karena itu realitas sosial yang ingin diciptakan adalah realitas sosial yang humanis, transendental, dan teologikal, maka rekonstruksi akuntansi harus dilakukan dengan nilai yang sama. Jadi, bukan sesuatu yang mustahil jika sebuah revolusi bisa dimulai dari suatu bentuk rekonstruksi akuntansi.

Rekonstruksi akuntansi dimulai dari pemikiran akuntansi kritis yang merupakan refleksi atas dominasi pemikiran akuntansi yang selama ini berkembang dalam aliran positivisme. Inti pemikiran kritis adalah suatu bentuk resistensi terhadap hegemoni dan dominasi atas suatu cara pandang bahwa kebenaran ilmu pengetahuan hanya bisa ditemukan dengan satu paradigma, yaitu positivisme. Sedangkan Akuntansi merupakan realitas sosial yang sangat kompleks, yang merupakan disiplin pengetahuan dan kekuatan, yang tidak bisa dilihat hanya dengan satu cara pandang 


\section{METODA PENELITIAN}

Pendekatan penelitian yang digunakan dalam penelitian ini adalah pendekatan dialektika dokumen, yang mana pendekatan ini akan memberikan gambaran tentang proses pencarian kebenaran ilmu pengetahuan, terutama yang tertera dalam teks dokumen baik katakata dan angka-angka (Christiawan dan Sawarjuwono, 2004). penelitian ini termasuk dalam ranah penelitian kualitatif yang merupakan suatu teropong atas fenomena sosial (khususnya akuntansi) dengan berbagai cara pandang (teropong), berbagai warna, bentuk, macam, perilaku dan rasa, misalnya dengan aliran konstruktivis, interpretif, feminis, postmodernis, strukturalis, teori kritis, dekonstruktivis dan masih banyak yang lainya (Sukoharsono, 2006). Di dalam penelitian ini, peneliti dituntut untuk memahami asumsi-asumsi filosofinya tentang objek dan subjek penelitiannya, yaitu mulai dari Ontologi, Epistemologi, Aksiologi, hingga ke Metodologinya. Dimana pemahaman tersebut akan membawa peneliti untuk apa atau atas kepentingan apa dia membangun sebuah ilmu pengetahuan (akuntansi). sedangkan Peneliti dalam setting pendekatan dialektika dokumen adalah sebagai instrumen penelitian. Sangat tepat jika peneliti sebagai instrumen penelitian, karena penelitilah yang akan menentukan keseluruhan skenario penelitian.

Sumber data utama dalam penelitian ini adalah laporan keuangan auditan perusahaan Manufaktur Sub Sektor Farmasi tahun 2018 dan 2019 yang tercatat di web site BEI, sub sektor ini sengaja peneliti pilih sekaligus untuk melihat sejauh mana dampaknya terhadap wabah corona yang saat ini melanda. Terdapat 10 (sepuluh) perusahaan sektor Farmasi yang terdaftar di Bursa Efek Indonesia yaitu (1). Darya Vario Laboratoria Tbk (DVLA); (2). Indofarma (Persero) Tbk (INAF); (3). Kimia Farma (Persero) Tbk (KAEF); (4). Kalbe Farma Tbk (KLBF); (5). Merck Indonesia Tbk (MERK);(6). PT. Phapros Tbk (PEHA);(7). Pyridam Farma Tbk (PYFA);(8). Merck Sharp Dohme Pharma Tbk (SCPI);(9). Industri Jamu \& Farmasi Sido Muncul Tbk (SIDO); (10). Tempo Scan Pasific Tbk (TSPC). Namun mengingat keterbatasan waktu yang dimiliki sehingga jenis data dari penelitian yang akan dilakukan merupakan data sekunder, yaitu bersifat data-data dokumenter tentang laporan keuangan perusahaan publik.

Prosedur analisis data dalam penelitian ini memiliki beebrapa tahapan yaitu: Langkah pertama, melakukan pengelompokan atau pemilahan pada laporan keuangan berdasarkan pada bidang operasi yang dijalankan perusahaan, misalnya bergerak di bidang perdagangan, jasa, atau manufaktur. Hal ini dilakukan supaya mempermudah dan mempercepat proses perbandingan; Langkah kedua, setelah peneliti memilah dokumen dalam hal ini laporan keuangan, akan melakukan analisa dengan membandingkan nilai setiap kelompok akun pada laporan keuangan auditan tahun 2018 yang dilaporkan dalam laporan keuangan auditan tahun 2018 dengan laporan keuangan 2018 yang dilaporkan dalam laporan keuangan auditan tahun 2019. jika peneliti menjumpai perbandingan nilai kelompok akun tidak sama dalam penyajiannya antar periode laporan keuangan, maka peneliti akan melanjutkan pada langkah berikutnya yaitu melakukan dialektika dengan opini Auditor dan catatan atas laporan keuangan; Langkah ketiga, peneliti akan melakukan dialektika kritis dengan dokumen lainnya. Proses dialeketika ini dilakukan dengan tujuan untuk melihat sejauh mana perusahaan menjelaskan adanya perbedaan penyajian kelompok akun dalam catatan atas laporan keuangan, opini auditor dan peraturan Bapepam. Sehingga peneliti bisa menarik suatu makna dari fenomena tersebut; Langkah keempat, ditarik kesimpulan dari proses dialeketika dokumen. Sebagai contoh akan disajikan beberapa kemungkinan kesimpulan yang dapat ditarik oleh peneliti berkaitan dengan dokumen: (a) Apabila suatu akun tidak konsisten dalam penyajiannya dan auditor tidak memberikan penjelasan dalam opininya dan catatan 
atas laporan keuangan, maka dapat disimpulkan adanya indikasi pelanggaran standar dan peraturan Bapepam tentang pedoman penyajian laporan keuangan; (b) Apabila suatu akun tidak konsisten dalam penyajiannya dan penjelasan dalam catatan atas laporan keuangan dan opini auditor tidak mengungkapkan alasan yang jelas maka dapat disimpulkan adanya ketidak benaran dalam proses audit atas laporan keuangan; (c) Informasi laporan keuangan yang merupakan sarana untuk memberikan informasi tentang kinerja perusahaan dan dijadikan dasar pengambilan keputusan ekonomi akan menjadi semu. Laporan keuangan dapat dikatakan sebuah informasi yang mencerminkan kinerja perusahaan sejauh dalam penyajiannya yang konsisten dan wajar; (d) Sebuah kiasan yang disesuaikan untuk laporan keuangan yang dipermukaannya tampak bagus, tetapi dibalik permukaan ada indikasi pelanggaran standar dan ketidakbenaran dalam proses auditnya adalah seperti buih dilautan yang tampak besar dan bagus, tetapi di bawah buih tersebut keruh dan kosong.

\section{HASIL}

\section{Konsistensi Dalam Penyajian Laporan Keuangan}

Konsistensi dalam penyajian laporan keuangan perusahaan publik merupakan sesuatu yang sangat penting tetap mempertahankan kepercayaan masyarakat. Laporan keuangan tahunan perusahaan publik merupakan informasi keuangan yang dipublikasikan kepada masyarakat (investor, calon investor, kreditor dan pemakai lainnya) yang akan dianalisis untuk mendukung keputusan investasi, kredit atau lainnya (FASB 1984). untuk membantu dalam melakukan analisis, laporan keuangan harus memiliki konsistensi dalam hal penyajian dan disajikan dengan format yang mudah dimengerti (Chistiawan, 2004). Kieso (2010:38) mengungkapkan bahwa suatu perusahaan dikatakan konsiten apabila menggunakan perlakuan akuntansi untuk kejadian serupa dari satu periode ke periode berikutnya, namun bukan berarti konsistensi melarang suatu perusahaan untuk melakukan perubahan. perubahan boleh dilakukan asalkan metode yang baru lebih preferable dari yang lama, dan harus diungkapkan dampak yang disebabkan dalam catatan atas laporan keuangan.

Dari proses pencarian data laporan keuangan yang tersaji pada Bursa Efek Indonesia (www.idx.co.id) diperoleh informasi bahwasanya dari 10 (sepuluh) perusahaan farmasi yang terdaftar di bursa, 2 (dua) diantaranya tidak melaporkan laporan keuangan tahunannya secara berurutan yaitu MERK Indonesia Tbk yang tidak menyajikan laporan keuangan tahun 2018 dan Merck Sharp Dohme Pharma Tbk d.h Schering Plough Indonesia Tbk yang tidak menyajikan laporan keuangan tahun 2019. Terdapat 4 (empat) perusahaan yang melakukan perubahan format laporan keuangan yaitu diantaranya melakukan penambahan akun yang dilaporkan perubahan tersebut yaitu Indofarma (Persero) Tbk, Kimia Farma (Persero) Tbk, Kalbe Farma Tbk, dan Phapros Tbk. Hal ini berarti hanya 4 (40\%) perusahaan yang stabil tidak melakukan perubahan apapun terhadap laporan keuangan tahunannya pada Bursa Efek Indonesia yaitu Darya Variao Laboratoria Tbk, Pyridam Farma Tbk Tempo Scan Pasific Tbk dan Industri Jamu \& Farmasi Sido Muncul Tbk.

Laporan Keuangan Indofarma Tbk. pada tahun 2019 disajikan lebih detail bila dibandingkan dengan tahun 2018. Penyajian yang lebih detail terdapat pada akun penjualan yaitu jika sebelumnya hanya menampilkan nilai penjualan saja, kali ini terdapat tambahan akun yang merupakan pecahan dari rekening penjualan (terbagi menjadi penjualan obat, penjualan alat kesehatan dan penjualan alat farmasi). Selain itu Indofarma Tbk juga melakukan revisi atas laporan keuangan tahunan 2018, namun tidak ada penjelasan secara detail mengapa revisi laporan ini dilakukan. Peneliti mencoba membandingkan laporan keuangan tahun 2018 sebelum dan sesudah revisi ternyata hasilnya tidak ada perbedaaan sehingga walapun melakukan perubahan dalam penyajian laporan keuangan, Indofarma 
termasuk sebagai perusahaan sektor farmasi yang konsisten dalam melaporkan laporan keuangannya pada Bursa Efek Indonesia.

\section{Gelembung-gelembung sabun dalam Penyajian Laporan Keuangan}

Halim (2008) menangkap fenomena bahwa informasi yang terkandung dalam laporan keuangan tahun 2004 dan 2005 ternyata sebanyak 60 persen bersifat "gelembunggelembung" informasi, sedangkan sebanyak 40 persen bersifat "cahaya" yang mencerminkan informasi realitas perusahaan apa adanya, sehingga dapat memunculkan dampak yang akan menyesatkan para penggunanya dalam pengembalian keputusan ekonomi. Setelah lewat sepuluh tahun apakah gelembung-gelembung ini masih ada?. Berdasarkan

Tabel 1.

Reklasifikasi Akun PT Kimia Farma Tbk

\begin{tabular}{|l|r|r|r|}
\hline \multicolumn{1}{|c|}{ akun } & $\mathbf{2 0 1 8}$ & \multicolumn{1}{c|}{ 2018* $^{*}$} & \multicolumn{1}{c|}{ Selisih } \\
\hline Aset Lancar & 5.369 .547 & 6.378 .008 & 1.008 .461 \\
\hline Aset Tidak Lancar & 4.090 .881 & 4.951 .082 & 860.201 \\
\hline Liabilitas jangka pendek & 3.744 .304 & 4.745 .842 & 1.001 .538 \\
\hline liabilitas jangka panjang & 2.329 .663 & 2.436 .990 & 107.327 \\
\hline Ekuitas & 3.356 .460 & 4.146 .258 & 789.798 \\
\hline Penjualan & 7.454 .115 & 8.459 .247 & 1.005 .132 \\
\hline Beban Pokok Penjualan & 4.673 .936 & 5.096 .045 & 422.109 \\
\hline Laba Kotor & 2.780 .178 & 3.363 .203 & 583.025 \\
\hline Laba Usaha & 765.017 & 982.516 & 217.499 \\
\hline Beban Keuangan & 187.291 & 227.220 & 39.929 \\
\hline Laba Sebelum Pajak & 577.726 & 755.296 & 177.570 \\
\hline Laba Tahun Berjalan & 401.793 & 535.085 & 133.292 \\
\hline Laba Komprehensif & 775.702 & 931.548 & 155.846 \\
\hline
\end{tabular}

Berdasarkan hasil reklasifikasi data keuangan PT Kimia Farma untuk tahun 2018 dapat terlihat adanya perbedaan data yang tersaji dimana seluruh akun memiliki nilai yang berbeda. jika dihitung nilai selisihnya diperoleh data bahwa nilai perbedaan 2018* (data 2018 yang dilaporkan tahun 2019) dengan 2018 untuk akun neraca mencapai 20\%, sedangkan pada laporan laba rugi mencapai $37 \%$ (bila dibandingkan dengan nilai penjualan). melihat adanya perbedaan ini peneliti melakukan analisis lebih lanjut dan ditemukan adanya satu baris kalimat dalam potongan opini hasil audit yaitu:

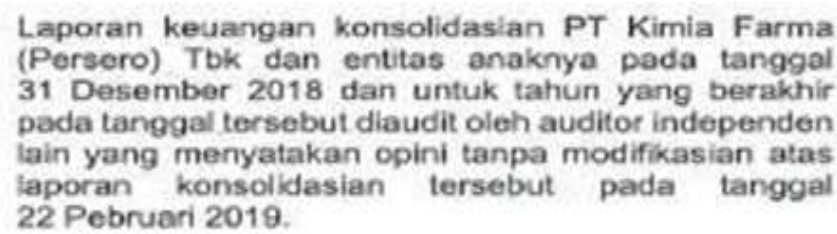

peneliti melihat adanya fenomena pergantian auditor sebagai salah satu sebab adanya perbedaaan data pada laporan keuangan yang tersaji, selain itu juga terdapat opini yang mengungkapkan bahwasanya auditor melakukan penyesuaian kembali terhadap laporan sebelumnya.

Gelembung sabun juga ditemukan pada salah satu akun di laporan kinerja PT Kalbe Farma, dimana laba tahun berjalan 2018 di laporan keuangan tahun 2018 tercatat sebesar 
Rp.2.459.261.964.757 sedangkan laba tahun berjalan 2018 di laporan keuangan tahun 2019 tercatat Rp. 2.497.261.964.757. setelah dianalisa kembali dengan mambaca seluruh laporan keuangan diketemukan bahwasanya terjadi kesalahan dalam memasukkan angka dimana nilai sebenarnya dari Laba Tahun Berjalan adalah Rp. 2.497.261.494.757.

Sedangkan gelembung sabun juga ditemukan dalam laporan keuangan Industri Jamu \& Farmasi Sido Muncul Tbk (SIDO), apabila melihat pada tabel 2 dibawah diketahui adanya 2 (dua) akun yang menunjukkan nilai yang berbeda yaitu Aset Lancar dan Aset Tidak Lancar, namun fakta yang unik adalah total aset yang diperoleh adalah sama. berdasarkan hasil catatan keuangan yang digali diperoleh informasi bahwa adanya penyesuaian kembali terhadap klasifikasi aset yang dimiliki.

Tabel 2

Reklasifikasi Akun Neraca SIDO

\begin{tabular}{|l|c|c|}
\hline \multicolumn{1}{|c|}{ Akun } & $2018^{*}$ & 2018 \\
\hline aset lancar & 1.543 .597 & 1.547 .666 \\
\hline aset tidak lancar & 1.794 .031 & 1.789 .962 \\
\hline total Aset & 3.337 .628 & 3.337 .628 \\
\hline
\end{tabular}

Secara keseluruhan, berdasarkan hasil pembahasan diketemukan bahwa terdapat 3 $(30 \%)$ perusahaan yang memiliki nilai berdeda dalam penyejian laporan keuangan sedangkan $2(20 \%)$ perusahaan tidak menyajikan laporan secara konsisten sehingga tidak bisa dilakukan analisis. hal ini berarti ada $5(50 \%)$ dari 10 perusahaan yang memberikan informasi tanpa menimbulkan penggalian lebih dalam.

\section{Kecantikkan dalam Penyajian Laporan Keuangan}

Menjadi cantik adalah suatu hal yang sangat didampakan oleh sebagian orang khususnya kaum wanita. Kecantikan itu dapat dimaknai sebagai sesuatu yang enak dilihat dan sesuatu yang indah. laporan keuangan yang tersaji juga akan menjadi lebih cantik jika tersaji secara baik dan jelas. para pembaca dapat dengan mudah memahami laporan yang disajikan dan tidak menimbulkan makna dualisme didalamnya. Kesulitan, keraguan dan ketidak jelasan adalah rasa yang seharusnya tidak muncul ketika sesorang membaca suatu informasi terutama apabila itu berkaitan informasi keuangan. namun perasaan inilah yang kemudian peneliti rasakan ketika membaca dan menganalisa laporan keuangan yang terdaftar di Bursa Efek Indonesia.

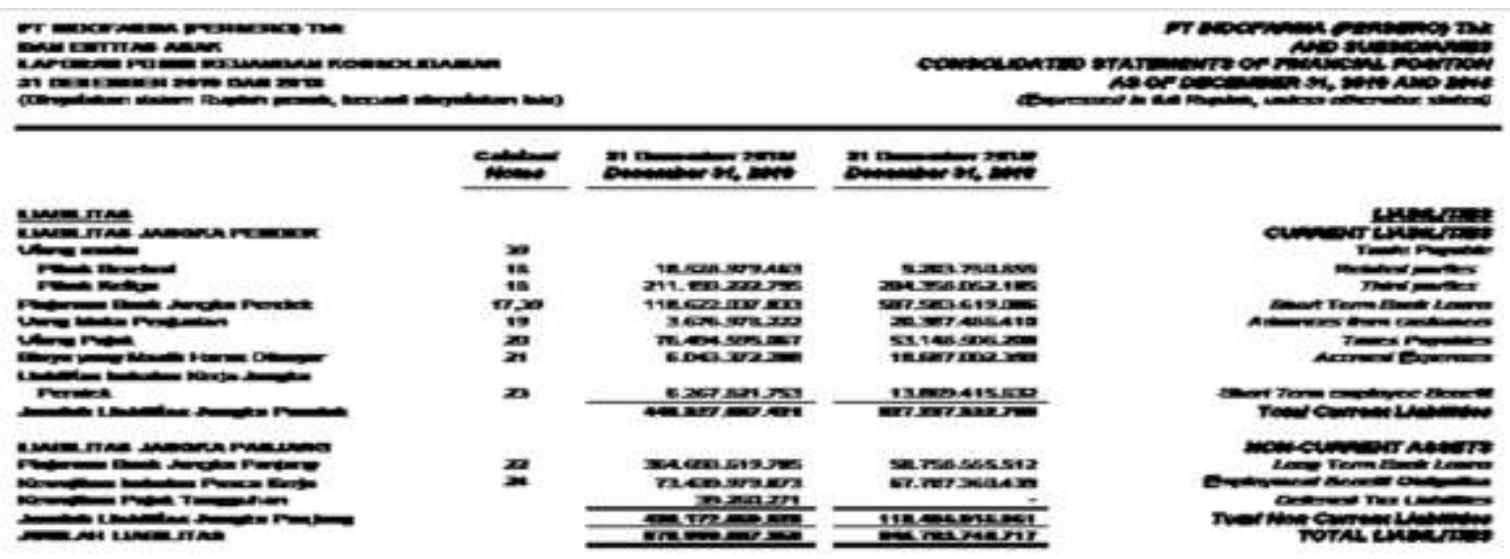


Gambar 1. Laporan Keuangan INAF 2019

Gambar di atas menunjukkan laporan keuangan INAF pada Tahun 2019, dimana INAF menyajikan laporan keuangan yang menampilan nilai yang tidak jelas, hal ini disebabkan karena font dan ketebalan huruf yang dipilih. hal ini mengakibatkan angka-angka yang tersaji tidak dapat terbaca, perubahan format ini menurut peneliti malah menjadi sesuatu yang tidak baik apabila dibandingkan dengan laporan tahun sebelumnya. sedangkan fenomena unik diperoleh dari laporan keuangan tahunan PYFA 2019 yang mana nilai dari masing-masing akun disajikan sebanyak 2 kali.

\section{KESIMPULAN}

Berdasarkan analisis dan pembahasan, secara keseluruhan terdapat 30\% perusahaan yang termasuk dalam sektor farmasi telah menyajikan laporan keuangan secara konsisten tanpa adanya gelembung-gelembung angka. sedangkan 70\%nya memimbulkan pertanyaan lebih dalam. namun demikian penyajian yang dilakukan oleh perusahaan-perusahaan tersebut mengalami perubahan baik secara reklasifikasi ataupun diakibatkan karena penyesuaian kembali. reklasifikasi akun yang terjadi sering kali diakibatkan karena penilaian aset lancar yang istimewa menjadi aset tidak lancar.

Hal-hal yang masih belum terpecahkan adalah apakah dengan adanya perubahan auditor menyebabkan gelembung-gelembung pada perusahaan tersebut terjadi. Namun fenomena lain yang juga diketemukan adalahnya $20 \%$ perusahaan tidak menyajikan laporan keuangannya secara berurutan. hal ini berarti kedua perusahaan tersebut tidak memenuhi kewajibannya untuk menyajikan laporan keuangan tahuanan yang dapat di baca oleh publik.

\section{Daftar Pustaka}

Barlian, R.S. 2003. Manajemen Keuangan. Edisi Kelima. Cetakan Kedua. Yogyakarta: Literata Lintas Media.

Christiawan, Y.J dan T. Sawarjuwono, 2004. Konsistensi Penyajian Laporan Keuangan Perusahaan Publik:Analisis Kritis atas opini Auditor dan Laporan Keuangan Auditan Tahun 2000. http://puslit.petra.ac.id/journals/accounting/

Habermas, Jurgen. 1970. Toward a Rational Society. Boston: Beacon Press 1971, Knowledge and Human Interest (asli : 1968, 'Erkenntnis und Interesse', transl. by Jeremy J. Saphiro), Beacon Press, Boston

1973, Theory and Practice (asli : 1971, 'Theorie und Praxis', transl by John Viertel), Polity Press, Cambridge

Harahap, S. S. 2009. Analisis Kritis Atas Laporan Keuangan. PT Raja Grafindo Persada. Jakarta

Hardiman, Budi, 1993, Menuju Masyarakat Komunikatif, Jogyakarta, Kanisiu. 2002. Melampaui Positivisme dan Modernitas. Penerbit Kanisius. Jakarta

Halim, Moch. 2008. Dialektika Kritis Laporan Keuangan atas Representasi Kinerja Perusahaan (studi Pada Industri food and Beverage yang go public di BEJ). Tesis. Malang: Fakultas Ekonomi Universitas Brawijaya

Harjito, 2008. Dasar-dasar Manajemen Keuangan. Edisi Keempat. Universitas Muhamadiyah. Malang 
Jusup, Al. Haryono. 2005. Dasar-dasar Akuntansi. Sekolah Tinggi Ilmu Ekonomi YKPN. Yogyakarta

Mahendra, Alfredo, Ni Luh Gede Sri Artini, AA Gede Swarjaya, 2012. Pengaruh Kinerja Keuangan Terhadap Nilai Perusahaan Manufaktur di Bursa Efek Indonesia. Jurnal Manajemen Strategi Bisnis dan Kewirausanaan. Vol 6. No 2

Orniati, Yuli. 2009. Laporan Keuangan sebagai Alat untuk Menilai Kinerja Keuangan. Jurnal ekonomi dan bisnis. ISSN: 0853-7283

Pongoh, Marcel. 2013. Analisis Laporan Keuangan Untuk Menilai Kinerja Keuangan Pt. Bumi Resources Tbk. Jurnal EMBA Vol 1, No.3. ISSN: 2303-1174

Sawarjuwono, Tjiptohadi, 1995, Language Change: A Critical Study of Habermas's Theory of Communicative Action. Disertasi.

Sutrisno, 2013. Manajemen Keuangan. Ekonisia. Yogyakarta

Tampubolon, M. 2005. Manajemen Keuangan (Finance Management). Cetakan Pertama. Bogor: Ghalia Indonesia. 